\title{
Review
}

Cerebrovascular Diseases
Cerebrovasc Dis 2018;46:159-169

DOI: $10.1159 / 000493863$
Received: June 29,2018

Accepted: September 18, 2018

Published online: October 9, 2018

\section{ACTA2 Cerebral Arteriopathy: Not Just a Puff of Smoke}

\author{
Joshua A. Cuoco ${ }^{\text {a-d }}$ Christopher M. Busch ${ }^{\mathrm{a}-\mathrm{d}}$ Brendan J. Klein ${ }^{\mathrm{a}-\mathrm{d}}$ \\ Michael J. Benko ${ }^{a-d}$ Rachel Stein ${ }^{d}$ Andrew D. Nicholson ${ }^{a-d}$ Eric A. Marvin ${ }^{a-d}$ \\ ${ }^{a}$ Carilion Clinic, Section of Neurosurgery, Roanoke, VA, USA; bVirginia Tech Carilion School of Medicine, Roanoke, \\ VA, USA; ' Virginia Tech School of Neuroscience, Blacksburg, VA, USA; ${ }^{\mathrm{d}}$ Edward Via College of Osteopathic Medicine, \\ Blacksburg, VA, USA
}

\section{Keywords}

ACTA2 - Cerebral arteriopathy $\cdot$ Stroke $\cdot$ Cerebrovascular bypass - Multiple smooth muscle dysfunction syndrome . Moyamoya disease

\section{Abstract}

Background: Missense mutations in the gene that codes for smooth muscle actin, ACTA2, cause diffuse smooth muscle dysfunction and a distinct cerebral arteriopathy collectively known as multisystemic smooth muscle dysfunction syndrome (MSMDS). Until recently, ACTA2 cerebral arteriopathy was considered to be a variant of moyamoya disease. However, recent basic science and clinical data have demonstrated that the cerebral arteriopathy caused by mutant ACTA2 exhibits genetic loci, histopathology, neurological sequelae, and radiographic findings unique from moyamoya disease. We conducted a literature review to provide insight into the history, clinical significance, and neurosurgical management of this recently described novel cerebral arteriopathy. Summary: We performed a literature search using PubMed with the key words "ACTA2 mutation," "ACTA2 cerebral arteriopathy," and "multisystemic smooth muscle dysfunction syndrome." Case reports with confirmed ACTA2 mutations

\section{KARGER}

() 2018 S. Karger AG, Basel

E-Mail karger@karger.com

www.karger.com/ced and cerebral arteriopathy were included in our review. Our literature search revealed 15 articles (58 cases) of confirmed ACTA2 cerebral arteriopathy. Distinctive features of this arteriopathy included an aberrant internal carotid circulation with dilatation of the proximal segments, occlusive disease at the distal segments, and dolichoectasia. As such, mutant ACTA2 predisposed patients to ischemic strokes as children. Direct and indirect cerebral revascularization procedures are the mainstay treatment options with varying degrees of success. Key Messages: ACTA2 cerebral arteriopathy is a recently described novel cerebrovascular disease seen in patients with MSMDS. Patients currently diagnosed with moyamoya disease who also have dysfunction of smooth muscle organs may benefit from reevaluation by a medical geneticist and ACTA2 genotyping.

(c) 2018 S. Karger AG, Basel

\section{Introduction}

Smooth muscle cells (SMCs) are foundational components of blood vessels and hollow viscera. Physiologically, vascular SMCs contract in response to stretch due to pulsatile blood flow. The molecular architecture necessary 

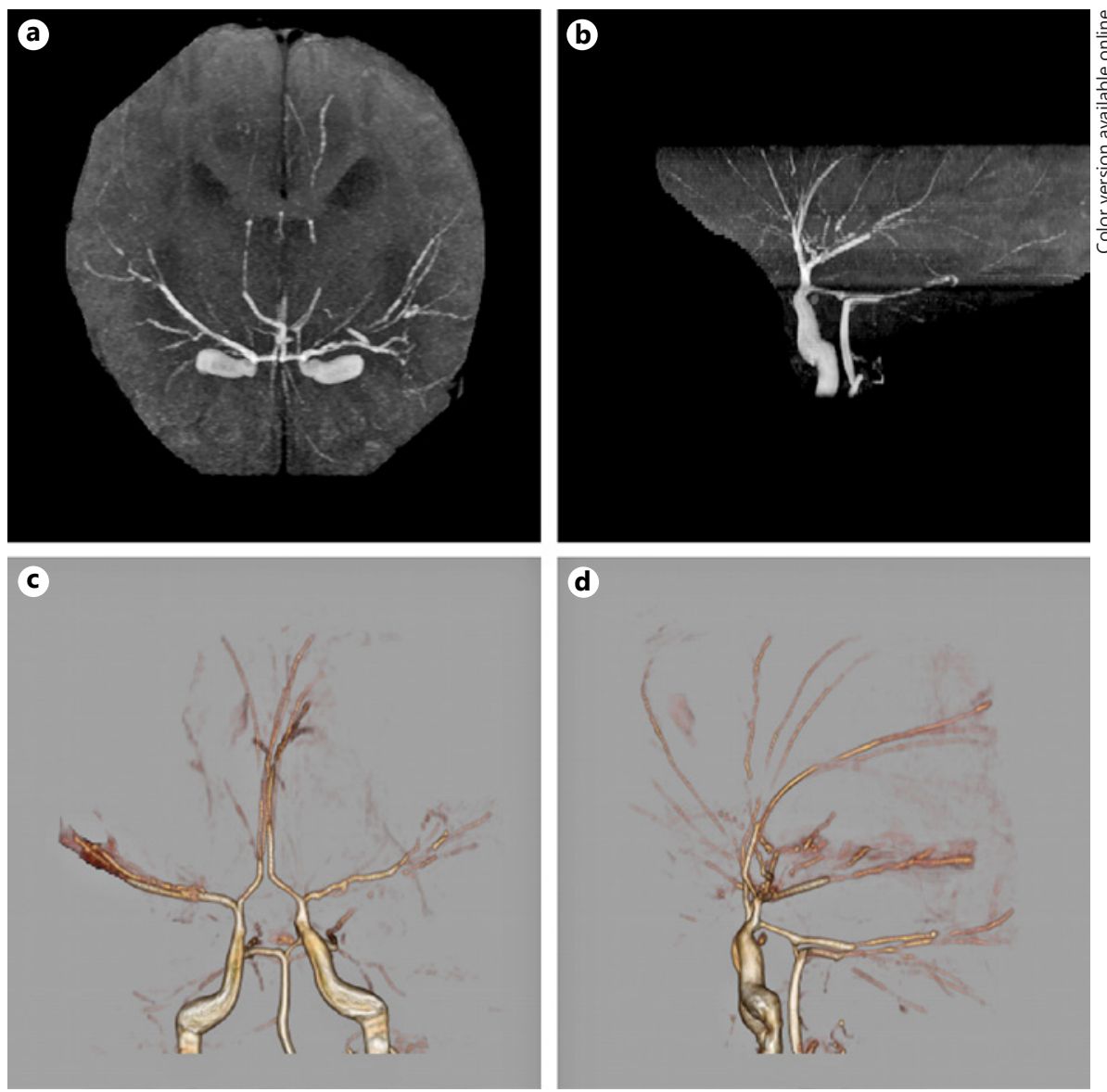

Fig. 1. Time-of-flight magnetic resonance angiography demonstrating fusiform dilatation of the proximal segments, stenosis of the distal segments, and dolichoectasia of the internal carotid artery. a Top down view. b Lateral view. c Coronal view of the post-processed image. $\mathbf{d}$ Lateral view of the post-processed image. (Case courtesy of Dr Chow, Radiopaedia.org, rID: 42870).

for SMC contraction consists of actin and myosin filaments crossing each other forming a matrix-like network. Six isoforms of actin are expressed in humans, each of which is encoded by a different gene. These actin isoforms include $2 \alpha$ isoforms specifically expressed in skeletal and cardiac tissue, $\beta$ and $\gamma$ cytosolic isoforms ubiquitously expressed in cells of muscle and non-muscle origin, and 2 isoforms of smooth muscle actin (SMA) [1]. The 2 isoforms of SMA include $\alpha 2$-SMA and $\gamma$-SMA, which are preferentially expressed in SMCs within vasculature and hollow viscera respectively. Importantly, the gene ACTA2 on chromosome 10q23.31 encodes $\alpha 2$-SMA [1]. Missense mutations in ACTA2, such as Arg179His, cause notable biochemical defects in vitro, such as impairment of actin-myosin interaction, which results in smooth muscle contractile dysfunction [1]. These molecular defects culminate in a vascular phenotype that demonstrates medial layer fibrosis and weakening of arterial vessels [2].

The clinical significance of physiologic SMA can be grossly appreciated in individuals who exhibit mutant
ACTA2. De novo heterozygous mutations substituting arginine for histidine, leucine, cysteine, or serine at position 179 in the ACTA2 gene are associated with the etiopathogenesis of the clinical entity known as multisystemic smooth muscle dysfunction syndrome (MSMDS) [12]. The pleiotropic effects of $A C T A 2$ missense mutations are vast. Most patients with MSMDS present with aortic aneurysms, patent ductus arteriosus, congenital mydriasis, and importantly, distinct cerebrovascular anomalies. These unique vascular features include an extensively diseased internal carotid circulation with dilatation of the proximal segments, occlusive disease at the distal segments, and dolichoectasia (Fig. 1, 2). As such, a mutated ACTA2 gene product predisposes patients to ischemic stroke.

Until recently, cerebral arteriopathy associated with MSMDS was considered to be a variant of moyamoya disease [2-4]. However, ACTA2 cerebral arteriopathy is now classified as a novel cerebrovascular disease with unique genetic loci, histopathologic findings, and cerebrovascular features. To date, only 58 cases of MSMDS with ACTA2 

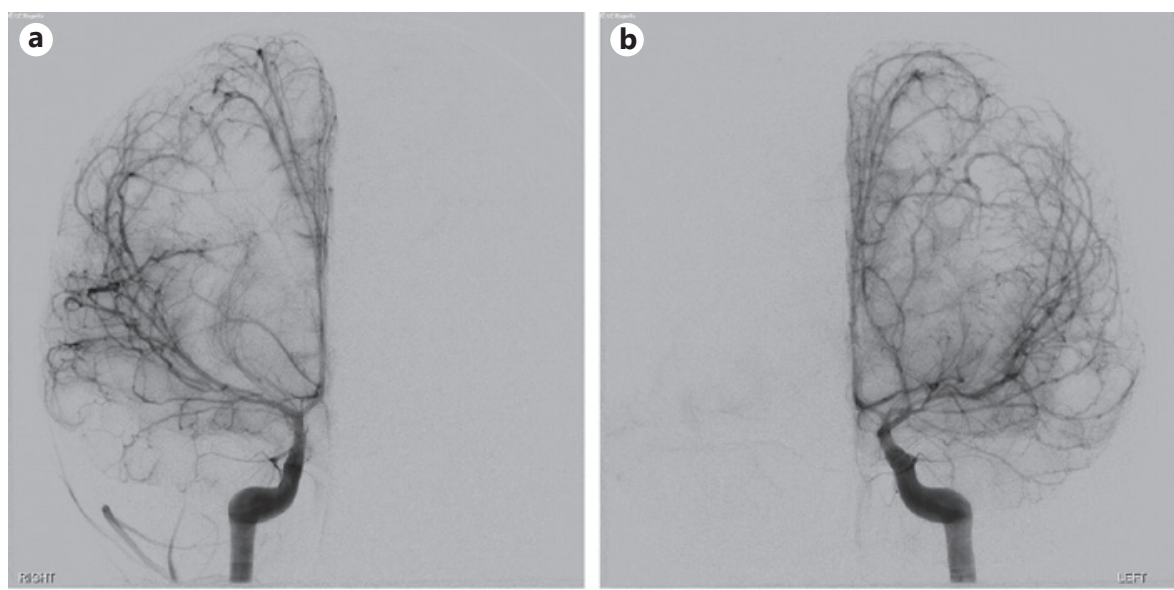

Fig. 2. Digital subtraction angiography demonstrating fusiform dilatation of the proximal segments, stenosis of the distal segments, and dolichoectasia of the internal carotid artery. a-b Frontal views. c-d Lateral views. (Case courtesy of Dr. Chow, Radiopaedia.org, rID: 42870).
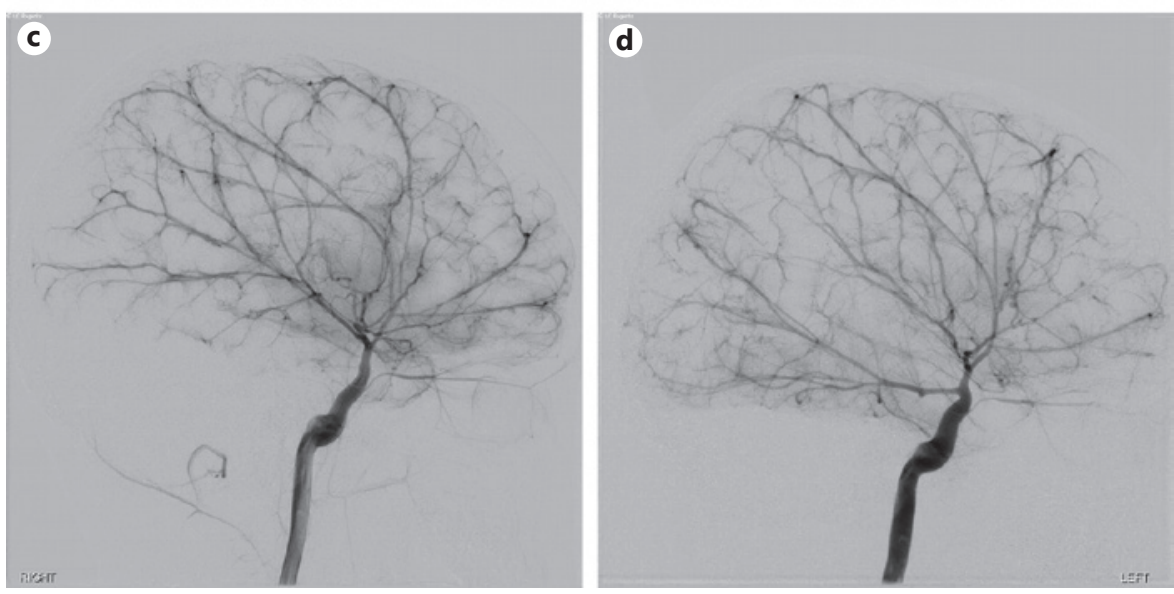

cerebral arteriopathy have been reported and confirmed via genotyping [2-16]. Here, we provide a literature review of ACTA2 cerebral arteriopathy encompassing the history of the disease from first observation to new classification, clinical significance and neurosurgical management strategies.

\section{First Observation to New Classification}

In 1985, Hanson et al. [17] reported 3 cases of congenital anomalies of the optic disc (i.e., 2 morning glory disc anomalies plus one disc coloboma) with angiographic aberrancies of the carotid circulation such as dolichoectasia and large trunk occlusions. The authors proposed that an insult to early embryogenesis might be responsible for the phenotypic manifestations observed in these cases [17]. Subsequent to these findings, numerous case studies were reported describing cerebrovasculature anomalies in combination with either ocular aberrations or cardiovascular malformations. However, in 2004,
Khan et al. [18] was first to report 2 patients with moyamoya disease and dolichoectatic internal carotid arteries plus bilateral fixed dilated pupils with iris hypoplasia and patent ductus arteriosus. The authors proposed that the combination of these separate congenital developmental diagnoses was not coincidence; rather, they postulated these cases were the clinical manifestations of an unknown syndromic entity likely driven by genetic mutation(s) [18]. Notably, neither of these cases were confirmed cases of MSMDS associated ACTA2 cerebral arteriopathy, as genotyping was not performed.

In 2007, Guo et al. [19] reported ACTA2 mutations in patients with thoracic aortic aneurysms and aortic dissections. Two years later, the same group led by Guo et al. [20] expanded their findings, reporting that mutations of ACTA2 caused a multitude of vascular pathologies in addition to thoracic aortic aneurysms and dissections including early onset coronary artery disease, premature ischemic stroke and moyamoya disease. The authors identified several ACTA2 mutations (i.e., Arg212Gln, Arg258Cys, and Arg258His) in the 6 patients with moyam- 
oya disease [19]. These data established that heterozygous ACTA2 mutations increased the risk for developing several vasculopathies, including moyamoya disease, and demonstrated a potential genetic predisposition to moyamoya disease $[19,20]$. However, 3 succeeding studies in 3 distinct ethic populations could not replicate the findings reported by Guo et al. $[19,20]$.

The first study to contradict the findings of Guo et al. $[19,20]$ was published by Shimojima and Yamamoto [21] who searched for ACTA2 mutations in Japanese patients diagnosed with moyamoya disease. Of note, most cases of moyamoya disease have been reported in the Japanese and Korean populations, as it is rare in nonAsian populations [22]. The authors sequenced the 9 coding exons of ACTA2 from 53 Japanese patients with moyamoya disease ( 46 familial cases and 7 non-familial cases), which did not reveal any ACTA2 mutations [21]. Second, Roder et al. [23] sequenced the exons of ACTA2 from 39 European patients with moyamoya disease, which did not reveal mutations previously identified. However, one novel missense mutation (Arg179His) on chromosome 6, not previously reported by Guo et al. $[19,20]$ was identified [23]. Third, $\mathrm{Hu}$ et al. [24] sequenced ACTA2 from 55 Chinese patients with moyamoya disease and did not find any ACTA2 mutations in these patients. Furthermore, several whole-genome linkage studies have shown the molecular etiology of moyamoya disease to be linked to the chromosomal regions 3p24.2-26, 6q25, 8q23, and 17q25.3, which do not include the locus of ACTA2 at 10q23.31 [25-28]. For example, Kamada et al. [29] recently identified the RNF213 gene (RNF213) on chromosome 17 (17q25-ter region) as a novel susceptibility gene for moyamoya disease in the East Asian population [28]. This group performed a genome-wide association study of 785,720 single nucleotide polymorphisms in 72 Japanese individuals with moyamoya disease and 45 Japanese healthy controls [29]. Genetic analysis of the RNF213 locus identified a founder mutation in RNF213 in $95 \%$ of familial cases of moyamoya disease and $79 \%$ of spontaneous cases of moyamoya disease compared to $1.4 \%$ in healthy controls [29]. These data suggested that ACTA2 mutations were not a major disease-causing gene for moyamoya disease.

In 2010, Milewicz et al. [2] identified 5 Northern European patients with a novel de novo heterozygous ACTA2 Arg179His missense mutation. These patients demonstrated a unique clinical syndrome characterized by widespread SMC dysfunction in organs throughout the body. All 5 patients exhibited ascending aortic aneu- rysms, patent ductus arteriosus, congenital mydriasis, hypotonic bladder, periventricular white matter hyperintensities and, importantly, significant cerebrovascular irregularities. Cerebral angiography in these patients demonstrated: (i) fusiform dilatation from the cavernous to the clinoid segments of the internal carotid artery, (ii) stenosis of the terminal segment of the internal carotid artery frequently extending into the sphenoidal segment of the middle cerebral artery and pre-communicating segment of the anterior cerebral artery, and (iii) absence of "moyamoya" basal collaterals [2]. Of note, one patient was reported to have colpocephaly. This case series established that de novo ACTA2 missense mutation causes a novel syndrome, coined MSMDS, which includes disease of the cerebrovasculature.

In 2012, Munot et al. [4] performed a detailed neuroimaging analysis of patients with heterozygous ACTA2 missense mutations. The analyses included 6 new patients ( 5 with Arg179His and one with Arg179Leu), 5 patients with $\operatorname{Arg} 179$ His reported by Milewicz et al. [2] and 1 patient with Arg179His reported by Richer et al. [5]. All patients exhibited a similar unique syndrome encompassing cerebrovascular disease, congenital mydriasis, and patent ductus arteriosus [4]. The authors identified cerebrovascular features similar to those observed by Milewicz et al. [2] in all patients. Key differences from moyamoya disease were dilatation of the internal carotid artery, a more diffuse arteriopathy with arterial ectasia, as well as the absence of distinguishing "moyamoya" basal collaterals. Imaging findings suggested that the change in vessel caliber from dilated to stenosed, although not absolute, may arise around the cavernous segment of the internal carotid artery. Of note, the cavernous segment is the location whereby the external elastic lamina dissipates from the walls of internal carotid arteries. This study reproduced the imaging findings by Milewicz et al. [2] and confirmed that patients with MSMDS exhibit a distinct cerebrovascular phenotype from moyamoya disease, which the authors termed ACTA2 cerebral arteriopathy [4].

\section{Histopathologic Correlates}

A novel study by Georgescu et al. [9] presented the first comprehensive histopathologic examination of ACTA2 cerebral arteriopathy of a MSMDS patient. The patient was a 31-year-old female with undiagnosed Arg179Hispositive MSMDS ("moyamoya disease," multiple aortic aneurysm repairs, surgical closure of a patent ductus ar- 
teriosus, congenital mydriasis, intestinal malrotation, and pulmonary disease) who expired 2 days after presenting to the emergency department with acute ischemic infarction of bilateral anterior cerebral arteries (ACA) and left middle cerebral artery (MCA). Compared to genderand age-matched controls, histological analysis of the patient's vasculature revealed significant intimal thickening in all of the major arteries of the anterior circulation and varying thickening in the arteries of the posterior circulation. As observed angiographically, the authors correlated reduced diameter and area of arterial lumens to be consequential to thickening of the intima layer [9]. Splitting between the intimal and media layer of the internal elastic lamina was observed, which, in addition to postmortem artifact, is suggestive of further adhesive dysfunction between the intima and media. Moreover, a marked increase in collagen and increased quantity of SMCs was found in the medial layer. The authors suggested that these findings, including increased wall thickness and marked media fibrosis, might account for the straight appearance of cerebral arteries found on imaging studies [9]. It should be noted that fibromuscular proliferation of the intima is also characteristic of moyamoya disease as well as atherosclerosis [30]. For example, Oka et al. [30] reported variable intimal elastofibrosis of the circle of Willis and its major branches in autopsy cases of moyamoya disease. However, contrary to moyamoya disease, 3 important differences were observed in the study by Georgescu et al. [9] including: (i) reduced folding of the internal elastic lamina compared to a more intricate folding occasionally reported in moyamoya disease, (ii) distinct media changes (i.e., fibrosis and SMC invasion) compared to media weakening seen in moyamoya disease and (iii) absent compensatory basal collaterals seen in moyamoya disease. Furthermore, the pathognomonic findings of atherosclerosis, such as macrophage accretion and cholesterol plaque formation, were not demonstrated in ACTA2 pathology samples.

\section{Clinical Significance}

Patients with MSMDS demonstrate discrete cerebrovascular anomalies that are fully penetrant with age. As such, these patients exhibit an elevated risk of developing vaso-occlusive strokes and various other neurologic sequelae, all of which may occur as early as the neonatal period (Table 1). In the largest MSMDS study to date, Regalado et al. [16] reported the clinical neurologic history of 33 patients (including 7 patients from Milewicz et al. [2] plus addendum) diagnosed with MSMDS. The median age of these patients was 12 years and the median age at diagnosis was 11 years. Twenty-one $(64 \%)$ were females and $12(36 \%)$ were males. Twenty-six were of European ancestry, 5 were Asian, 1 was African-American, and 1 was Hispanic [16]. These individuals exhibited various ACTA2 missense mutations at position 179 including Arg179His (24 patients), Arg179Cys (7 patients), Arg179Ser (1 patient), and Arg179Leu (1 patient). The authors reported proximal internal carotid artery stenosis in $77 \%$ of patients [16]. Fifty-three percent of patients demonstrated multi-vessel disease with the second most common site being one of the cerebral arteries (60\%). The most common neurologic complication reported in patient's histories was cerebral ischemic stroke. Stroke occurred in 8 females and one male (27\% of patients) occurring at a median age of 4 years [16]. The youngest age at stroke was reported in a 2-day-old child with infarction of the bilateral watershed areas and basal ganglia. Various other neurologic manifestations were reported in clinical histories including: developmental delay (19\%), seizure (18\%), hemiparesis (16\%), learning difficulties (7\%), lower-extremity spasticity (6\%), and upper extremity spasticity (3\%) [16]. It is postulated that such neurologic sequelae may be a consequence of chronic hypotension in the setting of a diseased intracranial circulation compromising cerebral blood flow and autoregulation. Interestingly, $95 \%$ of patients exhibited periventricular white matter signal changes on T2-weighted magnetic resonance imaging (MRI). White matter disease is a distinctive feature in patients with ACTA2 mutations, as such features are infrequently observed in moyamoya disease. Milewicz et al. [2] hypothesized that periventricular and subcortical white matter disease may result from the occlusion of small vessels or watershed lesions resulting from stenosis of the internal carotid circulation.

Brain development anomalies appear to be a prominent feature in patients specifically with the ACTA2 Arg179Cys mutation. Indeed, 3 of the 4 reported cases with this mutation demonstrated some degree of irregular brain development $[7,15]$. For example, Meuwissen et al. [7] reported a 2-year-old female with ACTA2 Arg179Cys; her MRI revealed a dysplastic corpus callosum with a small genu and an absent rostrum and lamina terminalis. The cingulate gyrus was abnormally positioned and sulcation of the medial cerebral hemispheres was abnormal, resulting in anomalous anatomy of the frontal lobes. de Grazia et al. [15] described the first case of newborn siblings with MSMDS who, coincidentally, had the ACTA2 Arg179Cys mutation and significant 
Table 1. Summary of neurologic symptomatology and radiographic imaging observed in patients with ACTA2 cerebral arteriopathy confirmed by genotyping

\begin{tabular}{|c|c|c|c|c|c|c|c|}
\hline $\begin{array}{l}\text { Author and } \\
\text { reference }\end{array}$ & Year & $\begin{array}{l}\text { Age at } \\
\text { diagnosis }\end{array}$ & Gender & Mutation & $\begin{array}{l}\text { Neurologic } \\
\text { symptomatology }\end{array}$ & $\begin{array}{l}\text { Cerebrovascular } \\
\text { imaging }\end{array}$ & Neuroimaging \\
\hline \multirow[t]{7}{*}{$\begin{array}{l}\text { Milewicz } \\
\text { et al. [2] }\end{array}$} & \multirow[t]{7}{*}{2010} & $11 \mathrm{y} / \mathrm{o}$ & $\mathrm{F}$ & $\mathrm{R} 179 \mathrm{H}$ & $\begin{array}{l}\text { Left hemiparesis, } \\
\text { headaches }\end{array}$ & \multirow{5}{*}{$\begin{array}{l}\text { Fusiform dilatation of ICA from } \\
\text { cavernous to clinoidal segments, } \\
\text { mild stenosis of terminal ICA } \\
\text { often extending into M1 and A1 } \\
\text { segments }\end{array}$} & $\begin{array}{l}\text { Focal infarct, WMSC, } \\
\text { parenchymal volume loss }\end{array}$ \\
\hline & & 14 y/o & M & $\mathrm{R} 179 \mathrm{H}$ & Left hemiparesis, headaches & & WMSC \\
\hline & & $17 \mathrm{y} / \mathrm{o}$ & $\mathrm{M}$ & $\mathrm{R} 179 \mathrm{H}$ & Developmental delay & & $\begin{array}{l}\text { WMSC, colpocephaly, } \\
\text { dysplastic corpus } \\
\text { callosum, small cerebellar } \\
\text { vermis }\end{array}$ \\
\hline & & $11 \mathrm{y} / \mathrm{o}$ & $\mathrm{F}$ & $\mathrm{R} 179 \mathrm{H}$ & Confusion, vertigo & & $\begin{array}{l}\text { WMSC, abnormal } \\
\text { perivascular spacing }\end{array}$ \\
\hline & & $26 \mathrm{y} / \mathrm{o}$ & $\mathrm{F}$ & $\mathrm{R} 179 \mathrm{H}$ & $\begin{array}{l}\text { Right hemispheric } \\
\text { arterial ischemic stroke }\end{array}$ & & $\begin{array}{l}\text { Focal arterial infarct, } \\
\text { WMSC }\end{array}$ \\
\hline & & $27.5 \mathrm{y} / \mathrm{o}$ & M & $\mathrm{R} 179 \mathrm{H}$ & None & $\mathrm{N} / \mathrm{A}$ & $\mathrm{N} / \mathrm{A}$ \\
\hline & & $16 \mathrm{y} / \mathrm{o}$ & $\mathrm{F}$ & R179S & None & $\begin{array}{l}\text { Stenosis of right supraclinoid } \\
\text { segment of ICA and aplastic } \\
\text { right MCA M1 segment, } \\
\text { stretched appearance of all } \\
\text { intracranial arteries }\end{array}$ & Colpocephaly \\
\hline \multirow[t]{3}{*}{$\begin{array}{l}\text { Moller } \\
\text { et al. [3] }\end{array}$} & \multirow[t]{3}{*}{2012} & $6 \mathrm{y} / \mathrm{o}^{*}$ & N/A & $\mathrm{R} 179 \mathrm{H}$ & Transient left hemiparesis & $\begin{array}{l}\text { Bilateral ICA dilatation proximal } \\
\text { to occlusion at terminal ICA }\end{array}$ & Right hemispheric infarct \\
\hline & & $3 \mathrm{y} / \mathrm{o}^{*}$ & $\mathrm{~N} / \mathrm{A}$ & $\mathrm{R} 179 \mathrm{H}$ & $\begin{array}{l}\text { Transient left hemiparesis, } \\
\text { headaches, impulsive } \\
\text { hyperactivity }\end{array}$ & Bilateral ICA occlusion & $\begin{array}{l}\text { Right hemispheric } \\
\text { infarct, WMSC }\end{array}$ \\
\hline & & $6 \mathrm{y} / \mathrm{o}^{*}$ & N/A & R179L & None & N/A & WMSC \\
\hline \multirow[t]{6}{*}{$\begin{array}{l}\text { Munot } \\
\text { et al. [4] }\end{array}$} & \multirow[t]{6}{*}{2012} & $3 \mathrm{y} / \mathrm{o}$ & $\mathrm{F}$ & $\mathrm{R} 179 \mathrm{H}$ & $\begin{array}{l}\text { Right hemiparesis, } \\
\text { recurrent TIAs }\end{array}$ & $\begin{array}{l}\text { Dilated proximal ICA, stenosed } \\
\text { lacerum segment ICA, straight } \\
\text { arterial course }\end{array}$ & $\begin{array}{l}\text { Focal arterial infarct, } \\
\text { WMSC, calcification from } \\
\text { old cerebral infarct }\end{array}$ \\
\hline & & $6 \mathrm{y} / \mathrm{o}$ & $\mathrm{F}$ & $\mathrm{R} 179 \mathrm{H}$ & $\begin{array}{l}\text { Right hemiparesis, } \\
\text { recurrent TIAs }\end{array}$ & \multirow{2}{*}{$\begin{array}{l}\text { Dilated proximal ICA, stenosed } \\
\text { cavernous ICA, straight arterial } \\
\text { course }\end{array}$} & $\begin{array}{l}\text { Focal arterial infarct, } \\
\text { WMSC }\end{array}$ \\
\hline & & $5 \mathrm{y} / \mathrm{o}$ & M & R179L & Headache & & WMSC \\
\hline & & $2 \mathrm{y} / \mathrm{o}$ & $\mathrm{F}$ & $\mathrm{R} 179 \mathrm{H}$ & Right hemiparesis & $\begin{array}{l}\text { Dilated proximal ICA, stenosed } \\
\text { lacerum segment ICA, straight } \\
\text { arterial course }\end{array}$ & $\begin{array}{l}\text { Focal infarct, WMSC, } \\
\text { parenchymal volume } \\
\text { loss }\end{array}$ \\
\hline & & $6 \mathrm{y} / \mathrm{o}$ & $\mathrm{M}$ & $\mathrm{R} 179 \mathrm{H}$ & None & $\begin{array}{l}\text { Dilated proximal ICA, stenosed } \\
\text { terminal ICA }\end{array}$ & WMSC \\
\hline & & $3 \mathrm{~m} / \mathrm{o}$ & $\mathrm{F}$ & $\mathrm{R} 179 \mathrm{H}$ & Gross motor delay & $\begin{array}{l}\text { Dilated proximal ICA, stenosed } \\
\text { cavernous ICA, straight arterial } \\
\text { course }\end{array}$ & Normal \\
\hline $\begin{array}{l}\text { Richer } \\
\text { et al. [5] }\end{array}$ & 2012 & $2 \mathrm{y} / \mathrm{o}$ & $\mathrm{M}$ & $\mathrm{R} 179 \mathrm{H}$ & Motor delay & $\begin{array}{l}\text { Diffuse narrowing of } \\
\text { supraclinoid ICA, small arteries } \\
\text { off circle of Willis with } \\
\text { narrowing and beading }\end{array}$ & WMSC \\
\hline $\begin{array}{l}\text { Amans } \\
\text { et al. [6] }\end{array}$ & 2013 & $3 y / o$ & $\mathrm{~F}$ & $\mathrm{R} 179 \mathrm{H}$ & $\begin{array}{l}\text { Lethargy, slurred } \\
\text { speech, dyspraxia }\end{array}$ & $\begin{array}{l}\text { Dilation of cervical ICAs with a } \\
\text { straightened course, infarct of M1 } \\
\text { segment of MCA }\end{array}$ & Focal infarct, WMSC \\
\hline $\begin{array}{l}\text { Meuwissen } \\
\text { et al. [7] }\end{array}$ & 2013 & $2 \mathrm{y} / \mathrm{o}$ & $\mathrm{F}$ & R179C & Normal & $\begin{array}{l}\text { Straight arteries from A2 segment } \\
\text { of ACA and M2-4 segments of } \\
\text { MCA }\end{array}$ & $\begin{array}{l}\text { WMSC, dysplastic } \\
\text { corpus callosum, } \\
\text { abnormal lobulation of } \\
\text { frontal hemispheres }\end{array}$ \\
\hline
\end{tabular}


Table 1. (continued)

\begin{tabular}{|c|c|c|c|c|c|c|c|}
\hline $\begin{array}{l}\text { Author and } \\
\text { reference }\end{array}$ & Year & $\begin{array}{l}\text { Age at } \\
\text { diagnosis }\end{array}$ & Gender & Mutation & $\begin{array}{l}\text { Neurologic } \\
\text { symptomatology }\end{array}$ & $\begin{array}{l}\text { Cerebrovascular } \\
\text { imaging }\end{array}$ & Neuroimaging \\
\hline $\begin{array}{l}\text { Georgescur } \\
\text { et al. [9] }\end{array}$ & 2015 & $31 \mathrm{y} / \mathrm{o}$ & $\mathrm{F}$ & $\mathrm{R} 179 \mathrm{H}$ & Unresponsive & $\begin{array}{l}\text { Straight course of most intracranial } \\
\text { arteries, narrowing of supraclinoid } \\
\text { right ICA and bilateral MCAs, } \\
\text { azygous A2 segment of ACA, left } \\
\text { ICA occlusion with absent left ACA }\end{array}$ & $\begin{array}{l}\text { Multiple arterial infarcts, } \\
\text { WMSC }\end{array}$ \\
\hline $\begin{array}{l}\text { Yetman } \\
\text { et al. [10] }\end{array}$ & 2015 & $2 \mathrm{y} / \mathrm{o}$ & $\mathrm{F}$ & $\mathrm{R} 179 \mathrm{H}$ & $\begin{array}{l}\text { Transient spasticity in } \\
\text { lower extremities, transient } \\
\text { hemiparesis, intermittent } \\
\text { seizures }\end{array}$ & $\begin{array}{l}\text { Narrowing of cavernous and } \\
\text { supraclinoid right ICA, narrowing } \\
\text { of MCA and ACA, aneurysmal } \\
\text { dilation of left ICA }\end{array}$ & $\begin{array}{l}\text { WMSC, cerebellar } \\
\text { tonsillar ectopia }\end{array}$ \\
\hline Yeung [11] & 2016 & 3 y/o & $\mathrm{F}$ & $\mathrm{R} 179 \mathrm{H}$ & Seizure, aphasia & Bilateral "moyamoya disease" & $\begin{array}{l}\text { Acute left hemispheric } \\
\text { infarct, chronic right } \\
\text { hemispheric stroke }\end{array}$ \\
\hline \multirow[t]{2}{*}{$\begin{array}{l}\text { Logeswaran } \\
\text { et al. [12] }\end{array}$} & 2016 & $4 \mathrm{~d} / \mathrm{o}$ & M & $\mathrm{R} 179 \mathrm{H}$ & Normal & $\begin{array}{l}\text { Fusiform dilation of bilateral } \\
\text { proximal ICAs }\end{array}$ & WMSC \\
\hline & & $26 \mathrm{y} / \mathrm{o}$ & $\mathrm{F}$ & $\mathrm{R} 179 \mathrm{H}$ & Normal & $\begin{array}{l}\text { Dilation of proximal ICA and } \\
\text { stenosis of terminal ICA, } \\
\text { straightened intracranial arteries }\end{array}$ & WMSC \\
\hline $\begin{array}{l}\text { Kantamneni } \\
\text { et al. [14] }\end{array}$ & & 7 y/o & N/A & $\mathrm{R} 179 \mathrm{C}$ & Progressive encephalopathy & & Multiterritorial infarcts \\
\hline \multirow[t]{2}{*}{$\begin{array}{l}\text { de Grazia } \\
\text { et al. [15] }\end{array}$} & 2017 & $2 \mathrm{w} / \mathrm{o}$ & $\mathrm{F}^{\wedge}$ & $\mathrm{R} 179 \mathrm{C}$ & Lethargic & $\begin{array}{l}\text { Proximal dilation of cavernous ICA } \\
\text { and stenosis of supraclinoid ICA, } \\
\text { absent carotid siphon configuration, } \\
\text { hypoplastic vertebra-basilar } \\
\text { circulation, straightened intracranial } \\
\text { arteries, stenosis of ACA and MCA }\end{array}$ & $\begin{array}{l}\text { Basal ganglia and thalamic } \\
\text { lesions, dysplastic corpus } \\
\text { callosum, parenchymal } \\
\text { volume loss }\end{array}$ \\
\hline & & $3 \mathrm{~d} / \mathrm{o}$ & $\mathrm{M}^{\wedge}$ & R179C & None & $\begin{array}{l}\text { Absent carotid siphon configuration, } \\
\text { hypoplastic posterior circulation, thin } \\
\text { right vertebral artery, aplastic left } \\
\text { vertebral artery, filiform basilar } \\
\text { artery, straightened arteries of circle } \\
\text { of Willis, stenosis of bilateral M1 } \\
\text { segments of MCA }\end{array}$ & $\begin{array}{l}\text { WMSC, abnormal } \\
\text { perivascular spacing, } \\
\text { incomplete } \\
\text { opercularization of insula }\end{array}$ \\
\hline
\end{tabular}

* Approximate age; ${ }^{\wedge}$ twins.

ICA, internal carotid artery; WMSC, white matter signal change; N/A: not available; TIA, transient ischemic attack; MCA, middle cerebral artery; ACA, anterior cerebral artery; y/o, years old; w/o, weeks old; d/o, days old; M, male; F, female. 
Table 2. Summary of the neurosurgical management in patients with ACTA2 cerebral arteriopathy confirmed by genotyping

\begin{tabular}{|c|c|c|c|c|c|c|c|}
\hline $\begin{array}{l}\text { Author and } \\
\text { reference }\end{array}$ & Year & Gender & $\begin{array}{l}\text { Age at } \\
\text { first stroke }\end{array}$ & $\begin{array}{l}\text { Age at } \\
\text { procedure }\end{array}$ & Type of procedure & $\begin{array}{l}\text { In-housepostloperative } \\
\text { complications }\end{array}$ & $\begin{array}{l}\text { Follow-up } \\
\text { complications }\end{array}$ \\
\hline \multirow[t]{2}{*}{$\begin{array}{l}\text { Moller } \\
\text { et al. [3] }\end{array}$} & \multirow[t]{2}{*}{2012} & $\mathrm{~N} / \mathrm{A}$ & $6 \mathrm{y} / \mathrm{o}^{*}$ & $6 \mathrm{y} / \mathrm{o}^{*}$ & $\begin{array}{l}\text { Two-step bilateral } \\
\text { neurosurgical bypass for } \\
\text { cerebral revascularization }\end{array}$ & $\begin{array}{l}\text { Ischemic infarction of right } \\
\text { hemisphere }\end{array}$ & $\begin{array}{l}\text { Unexpectantly expired at } \\
2 \text { years postoperative }\end{array}$ \\
\hline & & $\mathrm{N} / \mathrm{A}$ & $3 \mathrm{y} / \mathrm{o}^{*}$ & 4 y/o* & $\begin{array}{l}\text { Bilateral surgical } \\
\text { revascularization } \\
\text { (unspecified) }\end{array}$ & None & None \\
\hline $\begin{array}{l}\text { Georgescur } \\
\text { et al. [9] }\end{array}$ & 2015 & $\mathrm{~F}$ & $31 \mathrm{y} / \mathrm{o}$ & $28 \mathrm{y} / \mathrm{o}$ & Left STA EDAS & $\begin{array}{l}\text { Paresthesia, transient } \\
\text { hemiparesis }\end{array}$ & $\begin{array}{l}\text { Expired at } 31 \mathrm{y} / \mathrm{o} \text { due to } \\
\text { ischemic infarction of } \\
\text { bilateral ACA and left } \\
\text { MCA territories }\end{array}$ \\
\hline $\begin{array}{l}\text { Yetman } \\
\text { et al. }[10]\end{array}$ & 2015 & $\mathrm{~F}$ & $\mathrm{~N} / \mathrm{A}$ & $6 \mathrm{y} / \mathrm{o}$ & $\begin{array}{l}\text { Surgical revascularization } \\
\text { (unspecified) }\end{array}$ & $\mathrm{N} / \mathrm{A}$ & $\mathrm{N} / \mathrm{A}$ \\
\hline Yeung [11] & 2016 & $\mathrm{~F}$ & $3 \mathrm{y} / \mathrm{o}$ & $\mathrm{N} / \mathrm{A}$ & $\begin{array}{l}\text { Surgical revascularization } \\
\text { (unspecified) }\end{array}$ & $\mathrm{N} / \mathrm{A}$ & $\begin{array}{l}\text { Ischemic infarction at } \\
1 \text { month post-operative }\end{array}$ \\
\hline $\begin{array}{l}\text { Rutledge } \\
\text { et al. [13] }\end{array}$ & 2016 & $\mathrm{~F}$ & $3 \mathrm{y} / \mathrm{o}$ & $3 \mathrm{y} / \mathrm{o}$ & $\begin{array}{l}\text { 1st surgery: combined } \\
\text { right STA synangiosis and } \\
\text { temporalis muscle onlay } \\
\text { 2nd surgery: left STA to } \\
\text { ACA bypass using the left } \\
\text { PAA. Temporalis muscle } \\
\text { only on left }\end{array}$ & $\begin{array}{l}\text { 1st surgery: none } \\
\text { 2nd surgery: right hemiparesis } \\
\text { and expressive aphasia on POD } \\
3 \text { due to extensive acute ischemic } \\
\text { infarction involving parts of } \\
\text { the left ACA and MCA }\end{array}$ & $\begin{array}{l}\text { 1st surgery: recurrent } \\
\text { transient bilateral lower } \\
\text { extremity hemiparesis at } \\
3 \text { years post-operative } \\
\text { 2nd surgery: CT } \\
\text { angiogram at } 2 \text { months } \\
\text { revealed worsening } \\
\text { vasculopathy }\end{array}$ \\
\hline \multirow[t]{2}{*}{$\begin{array}{l}\text { Kantamneni } \\
\text { et al. [14] }\end{array}$} & \multirow[t]{2}{*}{2017} & $\mathrm{~N} / \mathrm{A}$ & $6 \mathrm{y} / \mathrm{o}$ & $8 \mathrm{y} / \mathrm{o}$ & Left EDAMS & None & $\begin{array}{l}\text { Right ischemic } \\
\text { hemispheric infarction at } \\
3 \text { years post-operative }\end{array}$ \\
\hline & & $\mathrm{N} / \mathrm{A}$ & $7 \mathrm{y} / \mathrm{o}$ & $\mathrm{N} / \mathrm{A}$ & Bilateral EDAMS & None & None \\
\hline \multirow[t]{4}{*}{$\begin{array}{l}\text { Regalado } \\
\text { et al. [16] }\end{array}$} & \multirow[t]{4}{*}{2018} & $\mathrm{~F}$ & $9 \mathrm{y} / \mathrm{o}$ & $\frac{9 \mathrm{y} / \mathrm{o}}{13 \mathrm{y} / \mathrm{o}}$ & \multirow{4}{*}{$\begin{array}{l}\text { Indirect EDAS in } 5 \\
\text { patients ( } 4 \text { bilateral, } \\
1 \text { unilateral) } \\
\text { Direct and indirect bypass } \\
\text { in } 1 \text { patient }\end{array}$} & \multirow[t]{4}{*}{$\mathrm{N} / \mathrm{A}$} & $\begin{array}{l}1 \text { patient expired at } \\
3 \text { years post-operative } \\
\text { due to stroke }\end{array}$ \\
\hline & & $\mathrm{M}$ & $\mathrm{N} / \mathrm{A}$ & $7 \mathrm{y} / \mathrm{o}$ & & & 2 patients expired due to \\
\hline & & $\bar{M}$ & $1 \mathrm{y} / \mathrm{o}$ & $14 \mathrm{y} / \mathrm{o}$ & & & unknown causes \\
\hline & & $\mathrm{F}$ & $32 \mathrm{y} / \mathrm{o}$ & $29 \mathrm{y} / \mathrm{o}$ & & & $\begin{array}{l}2 \text { patients had recurrent } \\
\text { TIAs }\end{array}$ \\
\hline
\end{tabular}

* Approximate age.

STA, superficial temporal artery; EDAS, encephaloduroarteriosynangiosis; ACA, anterior cerebral artery; MCA, middle cerebral artery; N/A, not available; PAA, posterior auricular artery; POD; post-operative day; CT, computerized tomography; EDAMS, encephaloduroarteriomyosynangiosis; TIA, transient ischemic attack; M, male; F, female; y/o, years old.

brain anomalies. Of note, both parents' DNA tested negative for ACTA2 mutations indicating mutation genesis was due to germ line mosaicism in both siblings. The first sibling, a 2-week-old female, exhibited thalamic and basal ganglia lesions, indicative of severe hypoxicischemic injury, and a dysplastic corpus callosum. The second sibling, a 3-day-old male, presented with lesions of the periventricular and callosal splenium also suggestive of hypoxic-ischemic damage. Moreover, the second sibling exhibited incomplete opercularization of the in- sula. These observations support that the gene product of ACTA2 may play an essential yet unknown role in brain development.

\section{Neurosurgical Management}

While direct and indirect cerebral revascularization techniques are recognized treatment modalities for patients with moyamoya disease, literature on revasculariza- 
tion outcomes in patients with ACTA2 cerebral arteriopathy is scarce (Table 2) $[4,31]$. Unfortunately, most of the literature reporting revascularization procedures for patient with ACTA2 arteriopathy does not specify the details of neurosurgical technique (i.e., direct versus indirect procedure). Munot et al. [4] reported a limited series of cerebral revascularization complication rates in 3 pediatric patients with mutant ACTA2. Two of the 3 patients had an arterial ischemic stroke after revascularization. Comparatively, in a series reported from the same institution, 3 of 73 pediatric patients $(4.1 \%)$ who underwent cerebral revascularization for moyamoya disease had an arterial ischemic stroke postoperatively [4]. Indeed, neurosurgical revascularization for moyamoya disease demonstrates a significant protective effect in preventing the recurrence of stroke; however, a similar reduction in the incidence of future stroke with revascularization is not observed in ACTA2 cerebral arteriopathy patients $[4,31]$. Moller et al. [3] described a 6-year-old who underwent a 2-step bilateral bypass revascularization procedure, which was complicated by significant right hemispheric ischemic infarction. A second patient reported by Moller et al. [3] was a 4 -year-old who underwent bilateral bypass for a previous right hemispheric infarction. The patient made a full recovery.

Georgescu et al. [9] reported a female patient who underwent a left superficial temporal artery (STA) encephaloduroarteriosynangiosis at 28 years of age. Postoperative complications were minimal including paresthesias and transient hemiparesis. However, the patient expired at 31 years of age due to extensive ischemic infarction of the bilateral anterior cerebral arteries and left middle cerebral artery territories. Kantamneni et al. [14] reported encephaloduroarteriomyosynangiosis (EDAMS) revascularization outcomes, compared to encephaloduroarteriosynangiosis by Georgescu et al. [9] in 2 patients with known ACTA2 arteriopathy. The first patient was diagnosed with mutant ACTA2 at 6 years of age after imaging revealed numerous cerebral infarctions. The patient underwent a left EDAMS at 8 years of age without postoperative complications. Three-year follow-up MRI revealed a new right hemispheric ischemic infarct. The second patient presented at 7 years of age with encephalopathy. Mutant ACTA2 was confirmed and MRI revealed multiterritorial infarcts. The patient underwent bilateral EDAMS with no postoperative complications. Kantamneni et al. [14] concluded that EDAMS can be implemented safely for ACTA2 cerebral arteriopathy and is an effective revascularization strategy in preventing future ischemic infarcts. Rutledge et al. [13] described a 6-year- old patient with ACTA2 cerebral arteriopathy who underwent both indirect and direct cerebral revascularization. The patient presented at 3 years of age with symptomatology consistent with MSMDS and an acute left-sided hemiparesis. She was found to have a right MCA ischemic infarct and diffuse cerebral arteriopathy. A right-sided combined STA synangiosis and temporalis muscle onlay was performed. The patient remained asymptomatic until 6 years of age when she developed transient bilateral lower extremity hemiparesis. Repeat imaging revealed progressive diffuse cerebral arteriopathy. The patient subsequently underwent a left STA to ACA bypass using the left posterior auricular artery as graft plus left temporalis muscle onlay. On postoperative day 3 , she developed right hemiparesis and expressive aphasia due to extensive acute ischemic infarction involving the left ACA and MCA. Although the patient was affected by extensive post-operative infarction, the authors concluded that the direct bypass might have prevented the magnitude of infarction involving the medial frontal lobe [13].

\section{Screening and Surveillance Recommendations}

Based on the clinical neurologic history of 33 patients (including 7 patients from Milewicz et al. [2] plus addendum) diagnosed with ACTA2 cerebral arteriopathy, Regalado et al. [16] proposed screening and surveillance recommendations for neurologic complications. The authors recommend a baseline brain MRI as well as head and neck magnetic resonance angiography at time of diagnosis to screen for ischemic insult and degree of cerebrovascular stenosis respectively [16]. Optimal surveillance intervals of ACTA2 cerebral arteriopathy is yet to be established as disease progression is not well understood; nevertheless, Regalado et al. [16] recommend transcranial Doppler ultrasonography as an imaging modality to monitor cerebrovascular disease progression. Moreover, the authors advise the reservation of conventional catheter angiogram for patients with focal neurologic deficits or evidence of critical or progressive stenosis of cerebrovasculature on transcranial Doppler ultrasonography or magnetic resonance angiography. Despite these surveillance recommendations for disease progression, there are currently no standard indications for neurosurgical revascularization. The absence of revascularization indications for ACTA2 arteriopathy may be due in part to the paucity of reported cases as well as the high risk of postoperative stroke in the limited number of cases that have been described. 


\section{Conclusions}

ACTA2 missense mutations cause diffuse dysfunction of smooth muscle and a unique cerebral arteriopathy. Indeed, ACTA2 arteriopathy exhibits genetic loci, histopathology, neurologic sequelae, and radiographic findings that are distinct from moyamoya disease. With each reported case, we gain a better understanding of this unique neurovasculopathy and further elucidate the potential role for neurosurgical intervention.

\section{Disclosure Statement}

The authors declare that they have no conflicts of interest to disclose.

\section{Funding Sources}

This research did not receive any specific grant from funding agencies in the public, commercial, or not-for-profit sectors.

\section{References}

1 Lu H, Fagnant PM, Krementsova EB, Trybus KM: Severe molecular defects exhibited by the R179H mutation in human vascular smooth muscle a-actin. J Biol Chem 2016;291:2172921739.

2 Milewicz DM, Ostergaard JR, Ala-Kokko LM, Khan N, Grange DK, Mendoza-Londono R, Bradley TJ, Olney AH, Ades L, Maher JF, Guo D, Buja LM, Kim D, Hyland JC, Regalado ES: De novo ACTA2 mutation causes a novel syndrome of multisystemic smooth muscle dysfunction. Am J Med Genet A 2010;152A: 2437-2443.

3 Moller HU, Fledelius HC, Milemicz DM, Regalado ES, Ostergaard JR: Eye features in 3 Danish patients with multisystemic smooth muscle dysfunction syndrome. Br J Ophthalmol 2012;96:1227-1231.

4 Munot P, Saunders DE, Milewicz DM, Regalado ES, Ostergaard JR, Braun KP, Kerr T, Lichtenbelt KD, Philip S, Rittey C, Jacques TS, Cox TC, Ganesan V: A novel distinctive cerebrovascular phenotype is associated with heterozygous Arg179 ACTA2 mutations. Brain 2012;135:2506-2514.

5 Richer J, Milewicz DM, Gow R, de Nanassy J, Maharajh G, Miller E, Oppenheimer L, Weiler G, O'Connor M: R179H mutation in ACTA2 expanding the phenotype to include prunebelly sequence and skin manifestations. Am J Med Genet A 2012;158A:664-668.

6 Amans MR, Stout C, Fox C, Narvid J, Hetts SW, Cooke DL, Higashida RT, Dowd CF, McSwain H, Halbach VV: Cerebral arteriopathy associated with Arg179His ACTA2 mutation. BMJ Case Rep 2013;bcr2013010997.

7 Meuwissen ME, Lequin MH, Bindels-de Heus K, Bruggenwirth HT, Knapen MF, Dalinghaus M, de Coo R, van Bever Y, Winkelman BH, Mancini GM: ACTA2 mutation with childhood cardiovascular, autonomic and brain anomalies and severe outcome. Am J Med Genet A 2013;161A:1376-1380.

8 Moosa AN, Traboulsi EI, Reid J, Prieto L, Moran R, Friedman NR: Neonatal stroke and progressive leukoencephalopathy in a child with an ACTA2 mutation. J Child Neurol 2012;28:531-534.
9 Georgescu MM, Pinho Mda C, Richardson TE, Torrealba J, Buja LM, Milewicz DM, Raisanen JM, Burns DK: The defining pathology of the new clinical and histopathologic entity ACTA2-related cerebrovascular disease. Acta Neuropathol Commun 2015;3: 81.

10 Yetman AT, Starr LJ, Bleyl SB, Meyers L, Delaney JW: Progressive aortic dilation associated with ACTA2 mutations presenting in infancy. Pediatrics 2015;136:e262-e266.

11 Yeung HH: Large pupils in infancy. Suspected aniridia. Multisystemic smooth muscle dysfunction syndrome secondary to an ACTA2 mutation. J Pediatr Ophthalmol Strabismus 2016;53:7-8.

12 Logeswaran T, Friedburg C, Hofmann K, Akintuerk H, Biskup S, Graef M, Rad A, Weber A, Neubauer BA, Schranz D, Bouvagnet P, Lorenz B, Hahn A: Two patients with the heterozygous $\mathrm{R} 189 \mathrm{H}$ mutation in ACTA2 and complex congenital heart defects expands the cardiac phenotype of multisystemic smooth muscle dysfunction syndrome. Am J Med Genet A 2016;173:959-965.

13 Rutledge WC, Choudhri O, Walcott BP, Benet A, Fox CK, Gupta N, Lawton MT: Indirect and direct revascularization of ACTA2 cerebral arteriopathy: feasibility of the superficial temporal artery to anterior cerebral artery bypass with posterior auricular artery interposition graft: case report. J Neurosurg Pediatr 2016;18:339-343.

14 Kantamneni T, Mondok LJ, Friedman N: Outcome of revascularization in patients with ACTA2 cerebral vasculopathy. Neurology 2017;88(16 suppl).

15 de Grazia J, Delgado I, Sanchez-Montanez A, Boronat S, Del Campo M, Vazquez E: Cerebral arteriopathy associated with heterozygous Arg179Cys mutation in the ACTA2 gene: report in 2 newborn siblings. Brain Dev 2017;39:62-66.

16 Regalado ES, Mellor-Crummey L, De Backer J, Braverman AC, Ades L, Benedict S, Bradley TJ, Brickner ME, Chatfield KC, Child A, Feist C, Holmes KW, Iannucci G, Lorenz B, Mark P, Morisaki T, Morisaki H, Morris SA, Mitch- ell AL, Ostergaard JR, Richer J, Sallee D, Shalhub S, Tekin M, Montalcino Aortic Consortium, Estrera A, Musolino P, Yetman A, Pyeritz R, Milewicz DM: Clinical history and management recommendations of the smooth muscle dysfunction syndrome due to ACTA2 arginine 179 alterations. Genet Med 2018, Epub ahead of print.

17 Hanson MR, Price RL, Rothner AD, Tomsak RL: Developmental anomalies of the optic disc and carotid circulation. a new association. J Clin Neuroophthalmol 1985;5:38.

18 Khan N, Schinzel A, Shuknecht B, Baumann F, Ostergaard JR, Yonekawa Y: Moyamoya angiopathy with dolichoectatic internal carotid arteries, patent ductus arteriosus and pupillary dysfunction: a new genetic syndrome? Eur Neurol 2004;51:72-77.

19 Guo DC, Pannu H, Tran-Fadulu V, Papke CL, Yu RK, Avidan N, Bourgeois S, Estrera AL, Safi HJ, Sparks E, Amor D, Ades L, McConnell V, Willoughby CE, Abuelo D, Willing M, Lewis RA, Kim DH, Scherer S, Tung PP, Ahn C, Buja LM, Raman CS, Shete SS, Milewicz DM: Mutations in smooth muscle alpha-actin (ACTA2) lead to thoracic aortic aneurysms and dissections. Nat Genet 2007;39:14881493.

20 Guo DC, Papke CL, Tran-Fadulu V, Regalado ES, Avidan N, Johnson RJ, Kim DH, Pannu H, Willing MC, Sparks E, Pyeritz RE, Singh MN, Dalman RL, Grotta JC, Marian AJ, Boerwinkle EA, Frazier LQ, LeMaire SA, Coselli JS, Estrera AL, Safi HJ, Veeraraghavan S, Muzny DM, Wheeler DA, Willerson JT, Yu RK, Shete SS, Scherer SE, Raman CS, Buja LM, Milewicz DM: Mutations in smooth muscle alpha-actin (ACTA2) cause coronary artery disease, stroke, and moyamoya disease, along with thoracic aortic disease. Am J Hum Genet 2009;84:617-627.

21 Shimojima K, Yamamoto T: ACTA2 is not a major-disease causing gene for moyamoya disease. J Hum Genet 2009;54:687-688.

22 Kim JS: Moyamoya disease: epidemiology, clinical features, and diagnosis. J Stroke 2016; 18:2-11. 
23 Roder C, Peters V, Kasuya H, Nishizawa T, Wakita S, Berg D, Schulte C, Khan N, Tatagiba M, Krischek B: Analysis of ACTA2 in European moyamoya disease patients. Eur J Paediatr Neurol 2011;15:117-122.

$24 \mathrm{Hu}$ FY, Zheng HB, Xu YM, Jiang Y, Zhou D: ACTA2 is not a major genetic risk gene for Chinese patients with moyamoya disease. Int J Stroke 2013;8:E43.

25 Ikeda H, Sasaki T, Yoshimoto T, Fukui M, Arinami T: Mapping of a familial moyamoya disease gene to chromosome 3p24.2-p26. Am J Hum Genet 1999;64:533-537.

26 Sakurai K, Horiuchi Y, Ikeda H, Ikezaki K, Yoshimoto T, Fukui M, Arinami T: A novel susceptibility locus for moyamoya disease on chromosome 8q23. J Hum Genet 2004;49: 278-281.

27 Mineharu Y, Liu W, Inoue K, Matsuura N, Inoue $\mathrm{S}$, Takenaka $\mathrm{K}$, Ikeda $\mathrm{H}$, Houkin $\mathrm{K}$, Takagi Y, Kikuta K, Nozaki K, Hashimoto N, Koizumi A: Autosomal dominant moyamoya disease maps to chromosome $17 \mathrm{q} 25.3$. Neurology 2008;70:2357-2363.

28 Fujimura M, Sonobe S, Nishijima Y, Niizuma K, Sakata H, Kure S, Tominaga T: Genetics and biomarkers of moyamoya disease: significance of RNF213 as a susceptibility gene. J Stroke 2014;16:65-72.

29 Kamada F, Aoki Y, Narisawa A, Abe Y, Komatsuzaki S, Kikuchi A, Kanno J, Niihori T, Ono M, Ishii N, Owada Y, Fujimura M,
Mashimo Y, Suzuki Y, Hata A, Tsuchiya S, Tominaga T, Matsubara Y, Kure S: A genome-wide association study identifies RNF213 as the first moyamoya disease gene. J Hum Genet 2011;56:34-40.

30 Oka K, Yamashita M, Sadoshima S, Tanaka K Cerebral haemorrhage in moyamoya disease at autopsy. Virchows Arch A Pathol Anat Histol 1981;392:247-261.

31 Research Committee on the Pathology and Treatment of Spontaneous Occlusion of the Circle of Willis; Health Labour Sciences Research Grant for Research on Measures for Infractable Diseases: Guidelines for diagnosis and treatment of moyamoya disease. Neurol Med Chir 2012;52:245-266. 